\title{
Penelitian
}

\section{Trichinellosis pada Babi di Kota Manado Provinsi Sulawesi Utara}

\author{
(Trichinellosis in pig in Manado North Sulawesi Province) \\ Syahdu Pramono ${ }^{1,2^{*}}$, Fadjar Satrija ${ }^{3}$, Trioso Purnawarman ${ }^{3}$ \\ 'Badan Karantina Pertanian, Balai Karantina Pertanian Kelas I Manado \\ ${ }^{2}$ Program Studi Kesehatan Masyarakat Veteriner Sekolah Pascasarjana Institut Pertanian Bogor, Bogor \\ ${ }^{3}$ Departemen Ilmu Penyakit Hewan dan Kesehatan Masyarakat Veteriner \\ Fakultas Kedokteran Hewan Institut Pertanian Bogor \\ *Penulis untuk korespondensi: syahdu_pramono@yahoo.com \\ Diterima 7 Mei 2015, Disetujui 23 September 2015
}

\begin{abstract}
ABSTRAK
Trichinellosis adalah penyakit zoonnotik yang berasal dari makanan yang disebabkan oleh cacing nematoda Trichinella spp. Penyakit ini masih kurang mendapatkan perhatian di negara maju dan negara berkembang. Parasit ini mempunyai distribusi yang sangat luas hampir di seluruh dunia. Tujuan dari penelitian ini adalah untuk mengkaji keberadaan trichinellosis pada daging babi di Manado. Penelitian ini menggunakan lintas sektional dengan total sampel otot maseter babi $(n=139)$ dan otot diafragma babi $(n=139)$ berasal dari 4 rumah potong hewan babi di Manado. Pengujian laboratorium terhadap Trichinella spp. menggunakan uji pool digesti terdeteksi larva yang diduga Trichinella spp. dalam satu pool yang terdiri dari 9 sampel otot diafragma babi. Pool yang terdeteksi positif kemudian secara individu diuji dengan menggunakan uji kompresi dan dilakukan pembuatan preparat dengan metode pengecatan Hemaktosili Eosin. Hasil dari pengujian individual tidak terdeteksinya Trichinella spp. pada sampel yang diuji. Berdasarkan hasil pengujian tersebut diatas daging babi yang diperiksa tidak terinfeksi oleh Trichinella spp.
\end{abstract}

Kata kunci: digesti, kompresi, Trichinella spp.

\begin{abstract}
Trichinellosis is a food-borne zoonotic disease caused by the nematode Trichinella spp. However it is still a neglected disease in development and developing country. This parasite has worldwide distribution in a worldwide. The aims of this study were to observe the occurance Trichinella spp. in pork in Manado. The research was conducted using cross sectional study. A total of pig masseter muscle $(n=139)$ and pig diaprhagmatic muscle $(n=139)$ came from 4 slaughter house in Manado. Laboratory examination of Trichinella larvae using pooled sample digestion method was detected one larva in a pooled batch of 9 pig diaprhagmatic muscle samples whereas the suspected positive findings were individually subjected to the compression method and Hematoxilin Eosin staining method. The result showed that the infected individual could not be identified. Based on these findings, the absence of Trichinella infection in pigs slaughtered pigs indicates that not infected by Trichinella spp.
\end{abstract}

Keywords: compression, digestion, Trichinella spp

\section{PENDAHULUAN}

Trichinellosis adalah penyakit zoonotik yang diakibatkan oleh infeksi cacing nematoda Trichinella spp. Penyakit ini menyebabkan kerugian pada manusia dan menjadi masalah epidemiologi di banyak negara setelah diketahui bahwa kehadiran Trichinella spp. di daging babi merupakan penyebab trichinellosis pada manusia (Schuppers 2010). Menurut Pozio (2005) Trichinella spp. tidak hanya ditemukan pada babi, namun juga pada banyak spesies hewan omnivora dan karnivora domestik maupun satwa liar.

Trichinellosis merupakan penyakit yang bersumber dari makanan. Manusia dapat terinfeksi larva Trichinella spp. melalui proses mengosumsi daging 
yang tidak dimasak secara sempurna. Hal ini umum di negara-negara berkembang, namun banyak kasus juga datang dari negara negara maju di Eropa dan Amerika Utara, karena daging babi mentah atau kurang matang dan binatang liar dapat dikonsumsi sebagai hidangan. Adanya penyakit yang tidak terdeteksi dengan tepat menyebabkan meluasnya penyakit di lapangan (Gottstein et al., 2009). Trichinellosis pada manusia telah dilaporkan di 55 negara (27,8\%) di seluruh dunia (Pozio, 2007). Oleh sebab itu pemeriksaan secara rutin terhadap Trichinella spp. di tempat pemotongan babi menjadi penting (Schuppers, 2010).

Secara serologis kejadian trichinellosis pada manusia pernah dilaporkan terjadi pada penduduk di Pulau Bali dimana 19,5\% terdeteksi terinfeksi Trichinella spp. Tiga wisatawan Italia yang mengunjungi Pulau Bali terinfeksi Trichinella spp. akibat mengosumsi daging babi. Infeksi Trichinella spp. pada babi domestik telah dilaporkan di Tapanuli, Sumatera, namun kebiasaan masyarakat lokal memasak atau memanggang daging babi hingga matang sangat efektif untuk menghambat transmisi ke manusia (Poizio, 2007). Studi prevalensi trichinellosis pada daging babi di Kota Kupang Provinsi Nusa Tenggara Timur yang dilakukan oleh Angi et al. (2014) menyatakan bahwa 0,9\% daging babi mengandung larva Trichinella spiralis.

Populasi babi di Provinsi sulawesi Utara pada tahun 2013 diperkirakan mencapai 409473 ekor (Ditjennakeswan, 2013). Olahan daging babi untuk konsumsi manusia di Kota Manado cukup beragam dan sangat digemari oleh masyarakat yang mempunyai kegemaran makan makanan khas minahasa. Menurut Kandow (2009), Jumlah penduduk etnis Minahasa adalah yang terbanyak diantara etnis yang ada di Provinsi Sulawesi Utara dan mempunyai suatu kebiasaan party yang diikuti dengan pesta makan atau makan makanan khas Minahasa yang sebagaian besar berasal dari babi. Makanan yang dianggap paling prestige adalah babi. Makanan yang dikonsumsi sehari harinya juga cenderung mengandung daging babi. Orang Minahasa makan daging babi sebagaimana orang kebanyakan penduduk Indonesia makan daging sapi. Kejadian infeksi oleh Trichinella spp. pada daging babi akan membahayakan kesehatan masyarakat dan tentunya akan mempuyai dampak terhadap kelangsungan peternakan babi di Provinsi Sulawesi Utara.

Dari hasil penelitian yang dilakukan oleh Kant et al. (2013), mengenai gambaran kebiasaan makan masyarakat di kelurahan Malalayang Kota Manado konsumsi daging babi mempunyai persentase tertinggi sebesar 65,5\% dilanjutkan dengan ikan 55,6\% dan daging ayam 34,4\%. Konsumsi daging babi yang kurang masak dalam pengolahannya mempuyai risiko menyebarkan penyakit yang disebabkan oleh Trichinella spp. Menurut Pozio (2007), Distribusi Trichinella spp. Berkaitan dengan budaya mengonsumsi daging babi mentah atau setengah matang, dan merupakan faktor utama yang mendukung infeksi pada manusia di negara-negara industri dan nonindustri.

Penelitian tentang kejadian trichinellosis yang dilakukan di Kota Manado sampai saat ini belum pernah dilakukan. Untuk itu perlu dilakukan kajian terhadap trichinellosis di Kota Manado sehingga dapat dikembangkan strategi pengawasan dan pengendalian dalam menghindari penularan trichinellosis ke manusia. Penelitian ini bertujuan untuk mengkaji kejadian trichinellosis pada babi peliharaan yang dipotong di rumah potong hewan babi milik pemerintah dan di tempat-tempat pemotongan hewan babi milik perseorangan.

\section{BAHAN DAN METODE}

\section{Waktu dan Tempat Penelitian}

Penelitian ini dilaksanakan selama tiga bulan dari Agustus sampai Oktober 2014. Pengambilan sampel dilakukan di Rumah Potong Hewan Babi Taas yang merupakan milik pemerintah daerah Kota Manado dan tempat pemotongan hewan babi milik perseorangan yang terdapat di Kota Manado Provinsi Sulawesi Utara. Pemeriksaan dan identifikasi terhadap larva Trichinella spp. pada otot dilakukan di Laboratorium Helminthologi Institut Pertanian Bogor dan pewarnaan jaringan otot dilakukan di Laboratorium Patologi Institut Pertanian Bogor.

\section{Desain Penelitian}

Penelitian ini dilakukan secara lintas seksional dengan mengambil sampel otot masseter dan diafragma babi yang dipotong di rumah potong hewan babi dan tempat pemotongan babi. Besaran sampel ditentukan dengan menggunakan software Win Episcope 2,0, dengan tingkat kepercayaan 95\% dan prevalensi yang diharapkan adalah 10\% serta tingkat kesalahan $5 \%$ sehingga diperoleh besaran sampel sebesar 139 sampel (Tabel 1).

Pengambilan sampel dilakukan di empat tempat pemotongan babi yang secara rutin melakukan pemotongan yaitu di Rumah Potong Hewan Babi Taas milik pemerintah daerah Kota Manado yang 
Tabel 1 Lokasi dan jumlah pengambilan sampel

\begin{tabular}{lcc}
\hline \multicolumn{1}{c}{ Lokasi Pengambilan Sampel } & \multicolumn{2}{c}{ Jumlah Sampel } \\
\hline & Masetter & Diafragma \\
RPH Babi & 51 & 51 \\
Pasar Karombasan & 34 & 34 \\
Pasar Perum & 34 & 34 \\
Pasar Bersihati & 20 & 20 \\
Jumlah & 139 & 139 \\
\hline
\end{tabular}

terletak di desa Taas dan di tempat pemotongan babi milik perseorangan yang terdapat di tiga lokasi yaitu yaitu Pasar Karombasan, Pasar Perum, dan Pasar Bersihati.

Trichinellosis pada daging babi tersebut dideteksi menggunakan metode digesti dan kemudian hasil yang positif pada uji digesti dilakukan uji dengan metode kompresi untuk melihat bentuk morphologi larva Trichinella spp. apakah termasuk golongan encapsulated atau non-encapsulated menggunakan mikroskop stereo, dan dilakukan pewarnaan Hematoxilin Eosin (HE) untuk mewarnai jaringan dan larva dari Trichinella spp. sehingga memudahkan dalam pengamatan morfologi larva.

\section{Metode Pemeriksaan}

\section{Metode Digesti}

Pemeriksaan sampel daging dengan metode digesti dilakukan untuk mendeteksi adanya kehadiran larva Trichinella spp. Digesti dilakukan pada sampel otot masing-masing 10 gram. Sampel diblender sampai homogen dan ditambahkan 50-100 mL laruran air kemudian diblender sampai campuran berbentuk cair, lalu ditambahkan 10 gram pepsin, $16 \mathrm{ml} \mathrm{HCL} 25 \%$ dan $200 \mathrm{~mL}$ air dan dicampur selama 5 detik. Sampel yang telah homogen dipindahkan ke gelas 3 liter yang berisi batang pengaduk. Kemudian ditambahkan 2 liter air ke dalam blender untuk pembilasan semua sisa homogenat dan tuang ke ke gelas 3 liter. Gelas 3 liter ditempatkan pada hotplate stirer yang dipanaskaan atau diruang inkubasi suhu $45^{\circ} \mathrm{C}+2{ }^{\circ} \mathrm{C}$, kemudian gelas ditutup dengan alumunium foil. Pengaduk diaktifkan dengan kecepatan tinggi untuk membuat deep vortek tanpa percikan. Cairan pencernaan dituangkan ke dalam 2 liter separator funnel 0,17-0,18 mm dan dibilas pada suhu kamar dengan air dan tuangkan melalui saringan ke dalam 2 liter separator funnel Setelah itu dikeringkan $40 \mathrm{~mL}$ cairan pencernaan dari separator funnel ke dalam conical tube $50 \mathrm{~mL}$ dan didiamkan selama 10 menit kemudian supernatan dibuang sebanyak $30 \mathrm{~mL}$. secara perlahan aduk larutan sisa dan pindahkan ke dalam cawan petri dan ditunggu minimal 1 menit untuk memungkinkan larva menetap ke bawah, kemudian menggunakan mikroskop stereo pembesaran 10-16x secara sistematis cawan petri diperiksa untuk kehadiran larva Trichinella spp. (OIE 2012).

\section{Metode Kompresi}

Sampel otot dipotong setipis mungkin menjadi sejumlah potongan dengan masing-masing potongan sepanjang serat otot. Selanjutnya sampel otot dikompresi antara dua pelat kaca sampai terlihat tembus pandang. Otot diperiksa secara individual untuk melihat bentuk morfologi larva Trichinella spp. menggunakan mikroskop stereo (OIE 2007).

\section{Metode Pewarnaan Hematoxilin Eosin (HE)}

Pembuatan preparat histopatologi dimulai dengan trimming sampel otot dan didehidrasi di dalam alkohol dengan konsentrasi bertingkat (alkohol 70\%, 80\%, 90\%, 95\%, alkohol absolut I dan II), xylol (I dan II) dan parafin (I dan II) dengan menggunakan tissue processor. Pencetakan adalah suatu proses penananaman jaringan dalam parafin sehingga terbentuk blok parafin. Proses ini dikerjakan dengan bantuan alat (embedding console) yang dilengkapi dengan hot plate dan tempat stock parafin cair sehingga pengaturan posisi jaringan dapat dilakukan dengan baik. Cetakan diisi dengan parafin cair kemudian jaringan diletakkan di dalamnya dengan menggunakan pinset. Blok parafin yang sudah setengah beku diberi label untuk memudahkan identifikasi jaringan. Tahap selanjutnya adalah pendinginan blok parafin pada suhu $4-5{ }^{\circ} \mathrm{C}$. Pemotongan jaringan dilakukan dengan menggunakan alat mikrotom dengan ketebalan irisan 4-5 $\mu \mathrm{m}$. Hasil potongan jaringan yang didapat ditempelkan pada gelas objek dan dimasukkan ke dalam inkubator 
dengan suhu $37^{\circ} \mathrm{C}$ selama 24 jam sampai jaringan melekat sempurna (Samuelson, 2007).

Pewarnaan Hematoksilin-Eosin (HE) merupakan pewarnaan dengan menggunakan dua jenis zat warna, yaitu Mayer Hematoksilin dan Eosin. Pewarnaan $\mathrm{HE}$ dimulai dengan pencelupan jaringan pada larutan xylol I lalu berturut-turut xylol II, xylol III, alkohol absolut, alkohol 96\%, dan alkohol $70 \%$ masing-masing selama satu menit dan dicuci dengan air selama tiga puluh detik.

Selanjutnya dilakukan pencelupan ke dalam pewarna Mayer Hematoksilin selama satu menit dilanjutkan dengan mencuci dengan air selama tiga puluh detik. Kemudian preparat dicelupkan tiga kali ke dalam lithium karbonat dan dibilas kembali dengan air selama tiga puluh detik. Tahap selanjutnya dilakukan pencelupan ke dalam Eosin selama dua menit tiga puluh detik dan dibilas kembali selam tiga puluh detik. Kemudian dilakukan pencelupan kembali ke dalam alkohol bertingkat mulai dari $70 \%, 80 \%$, dan $96 \%$ sebanyak sepuluh celupan untuk alkohol absolut dilakukan sebanyak lima belas celupan. Berikutnya, yang terakhir adalah melakukan pencelupan ke dalam xylol I, xylol II, xylol III dan xylol IV selama masing-masing satu menit dan selanjutnya ditutup dengan cover glass (Samuelson, 2007). Pengamatan dilakukan dengan menggunakan mikroskop cahaya dengan perbesaran obyektif 10x sampai dengan 40x, pada beberapa bidang pandang hingga gambaran histopatologi dapat didiskripsikan secara jelas.

\section{Analisis Data}

Data yang diperoleh di analisis secara deskriptif dengan menyajikan hasil uji keberadaan Trichinella spp. pada daging babi di Kota Manado Sulawesi Utara, dalam bentuk tabel dan gambar.

\section{HASIL}

\section{Uji Digesti dengan Metode Magnetic Stirer}

Hasil pengujian dengan uji digesti terhadap 278 sampel yang terbagi dalam 28 pool masing masing 139 sampel otot maseter dalam 14 pool dan 139 sampel otot diafragma dalam 14 pool diperoleh hasil diduga positif pada satu uji digesti otot diafragma dengan kode pool P.14 (Tabel 2). Gambaran mikroskopik hasil uji digesti yang diduga larva Trichinella spp. dapat dilihat pada Gambar 1.

\section{Metode Kompresi}

Hasil pemeriksaan dengan metode kompresi terhadap 9 sampel individu (dari satu uji digesti yang positif) dengan stereomikroskop terhadap keberadaan encapsulated dan non-encapsulated larva Trichinella spp. didapatkan tidak satupun dari sampel terdeteksi larva Trichinella spp. (Tabel 3). Gambaran mikroskopik hasil uji kompresi dapat dilihat pada Gambar 2.

Tabel 2 Hasil dari Uji Digesti

\begin{tabular}{|c|c|c|}
\hline \multirow{2}{*}{ Kode Pool } & \multicolumn{2}{|c|}{ Hasil Pool Digesti } \\
\hline & Maseter & Diafragma \\
\hline P.1 & Tidak terdeteksi & Tidak terdeteksi \\
\hline P.2 & Tidak terdeteksi & Tidak terdeteksi \\
\hline P.3 & Tidak terdeteksi & Tidak terdeteksi \\
\hline P.4 & Tidak terdeteksi & Tidak terdeteksi \\
\hline P.5 & Tidak terdeteksi & Tidak terdeteksi \\
\hline P.6 & Tidak terdeteksi & Tidak terdeteksi \\
\hline P.7 & Tidak terdeteksi & Tidak terdeteksi \\
\hline P.8 & Tidak terdeteksi & Tidak terdeteksi \\
\hline P.9 & Tidak terdeteksi & Tidak terdeteksi \\
\hline P.10 & Tidak terdeteksi & Tidak terdeteksi \\
\hline P.11 & Tidak terdeteksi & Tidak terdeteksi \\
\hline P.12 & Tidak terdeteksi & Tidak terdeteksi \\
\hline P.13 & Tidak terdeteksi & Tidak terdeteksi \\
\hline P.14 & Tidak terdeteksi & Terdeteksi \\
\hline
\end{tabular}



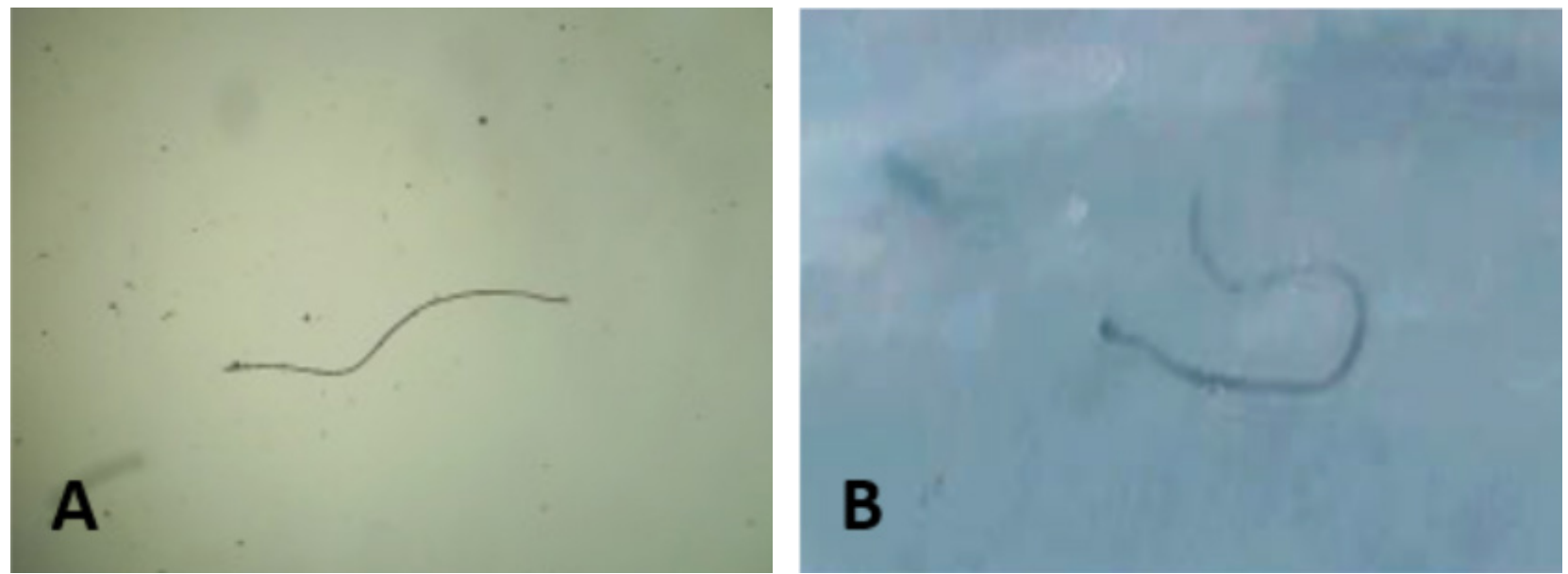

Gambar 1 (A) Sampel otot babi yang diperiksa menggunakan uji digesti di bawah stereomikroskop dengan perbesaran 10 kali yang diduga merupakan larva Trichinella spp. (B) Kontrol positif Trichinella spp. (Angi et al., 2014).
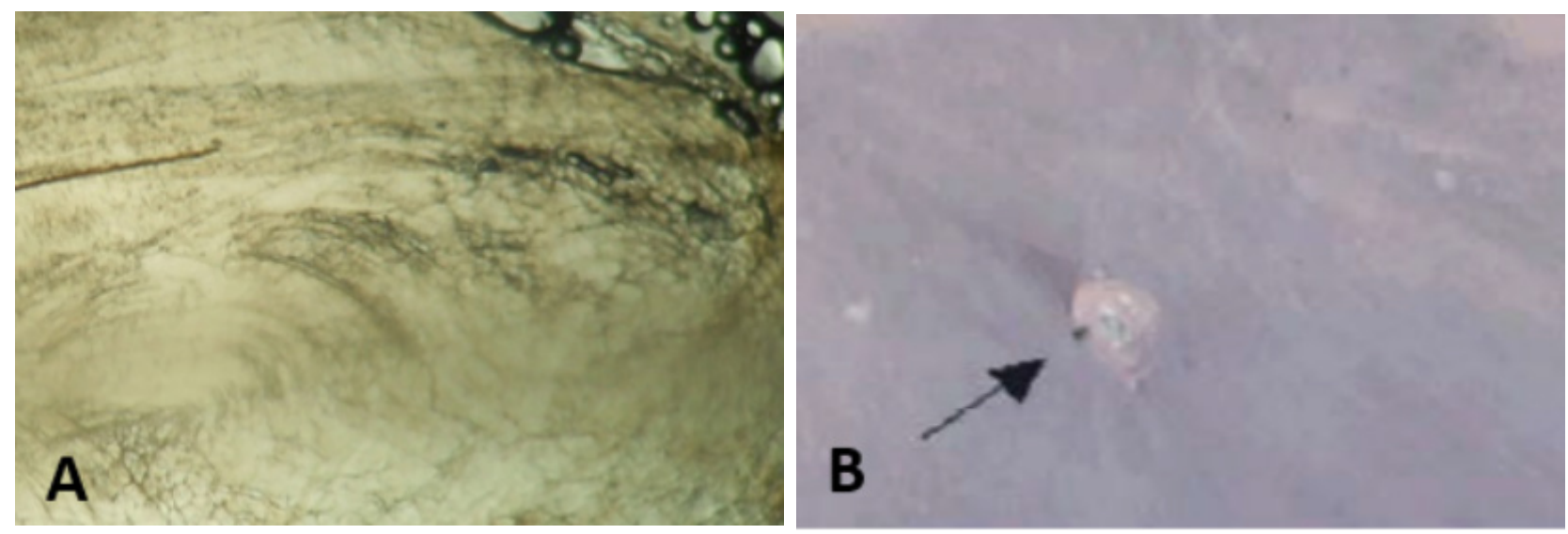

Gambar 2 (A) Sampel otot babi yang diperiksa menggunakan uji kompresi di bawah stereomikroskop dengan perbesaran 10 kali. (B) Kontrol positif (tanda panah) menunjukkan Trichinella spiralis. (Angi et al. 2014).

Tabel 3 Hasil pemeriksaan dengan uji kompresi

\begin{tabular}{cc}
\hline Kode Sampel & Hasil Pemeriksaan \\
\hline D 131 & Tidak Terdeteksi \\
D 132 & Tidak Terdeteksi \\
D 133 & Tidak Terdeteksi \\
D 134 & Tidak Terdeteksi \\
D 135 & Tidak Terdeteksi \\
D 136 & Tidak Terdeteksi \\
D 137 & Tidak Terdeteksi \\
D 138 & Tidak Terdeteksi \\
D 139 & Tidak Terdeteksi
\end{tabular}

\section{Metode Pewarnaan HE}

Pewarnaan jaringan dengan metode HE dilakukan pada sampel yang diduga positif terhadap Trichinella spp. Hasil dari pewarnaan ini terhadap sampel yang diuji setelah dibandingkan dengan kontrol adalah tidak terdeteksinya larva Trichinella spp. (Tabel 4). Gambaran mikroskopik hasil pewarnaan HE dapat dilihat pada Gambar 3.

\section{PEMBAHASAN}

Pemeriksaan daging babi dengan metode langsung untuk mendeteksi larva Trichinella spp. didisain untuk mencegah trichinellosis klinis pada 

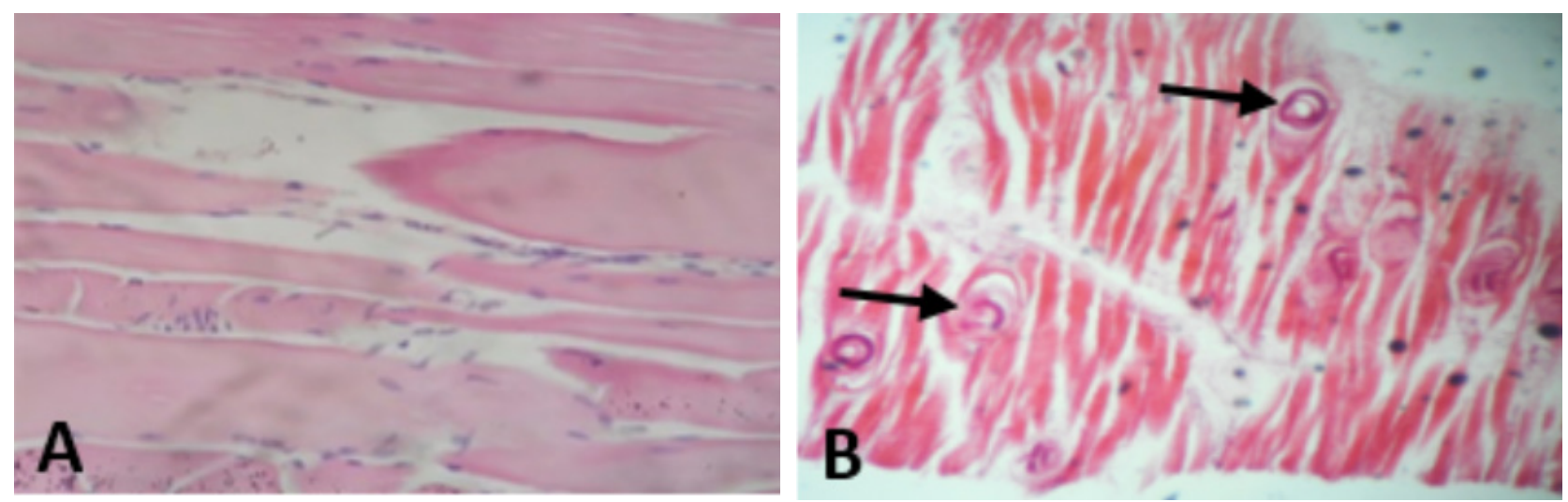

Gambar 3 (A) Hasil pemeriksaan sampel otot babi yang diperiksa menggunakan pewarnaan HE di bawah stereomikroskop. (B) Kontrol positif trichiellosis (tanda panah).

Tabel 4 Hasil pemeriksaan dengan pewarnaan HE

\begin{tabular}{cc}
\hline Kode Sampel & Hasil Pemeriksaan \\
\hline D 131 & Tidak Terdeteksi \\
D 132 & Tidak Terdeteksi \\
D 133 & Tidak Terdeteksi \\
D 134 & Tidak Terdeteksi \\
D 135 & Tidak Terdeteksi \\
D 136 & Tidak Terdeteksi \\
D 137 & Tidak Terdeteksi \\
D 138 & Tidak Terdeteksi \\
D 139 & Tidak Terdeteksi \\
\hline
\end{tabular}

manusia tetapi tidak untuk mencegah infeksi. Identifikasi larva Trichinella spp. pada sampel otot babi terbatas pada pemeriksaan postmortem. Metode yang mempunyai sensitivitas tinggi untuk mendeteksi larva Trichinella spp. dalam sampel otot sangat diperlukan. Keberhasilan metode ini dipengaruhi oleh ukuran sampel, jenis otot yang dipilih untuk pengambilan sampel, dan metode tertentu yang digunakan (Gottstein et al., 2009).

Menurut Schuppers et al. (2010), babi yang terinfeksi mungkin tidak terdeteksi positif selama pengujian dengan pengujian menggunakan metode pooled digesty. Sensitivitas konfirmasi uji digesti tidak diketahui secara pasti, karena tergantung pada pemilihan otot, ukuran sampel dan kepadatan larva. Metode digesti mempunyai limit deteksi 1 sampai 3 larva per gram sampel otot. Minimum 1 gram sampel otot cukup untuk mendeteksi Trichinella spp. dimana tujuannya untuk menunjukkan adanya infeksi oleh Trichinella spp. (Karn et al., 2008). Di atas kepadatan larva 3 sampai 5 larva per gram (LPG), sensitivitas 100\% tercapai, tapi di ba- wah 1 LPG sensitivitas turun menjadi 40\%. Karena 15 sampai $20 \%$ dari babi yang terinfeksi secara alami mempunyai kepadatan larva <1 LPG, menyebabkan babi yang terinfeksi tidak dapat dideteksi dengan metode ini (Schuppers, 2010).

Ada beberapa metode yang dikembangkan dalam digesti dan dalam penelitian ini menggunakan metode magnetic stirer. Metode dengan magnetic stirer dianggap sebagai gold standard karena metode ini khusus dirancang untuk sampel yang dikumpulkan, dan telah mengalami validasi studi. Penelitian yang dilakukan oleh Gottstein et al. (2009) menunjukkan bahwa dalam uji coba validasi dari metode magnetic stirrer, kepadatan larva lebih dari 3 LPG secara konsisten terdeteksi dengan ukuran sampel yang diterima saat ini adalah dari 1 gram sampel, sedangkan kepadatan larva dari 1,0 sampai 1,9 LPG diperlukan ukuran sampel 3 gram sampai 5 gram.

Bentuk tampilan yang paling membedakan larva Trichinella adalah stichosome yang terdiri dari serangkaian sel diskoid lapisan esofagus dan menempati setengah bagian depan dari tubuh cacing. Larva Trichinella mungkin muncul melingkar (saat dingin), motil (ketika hangat) atau berbentuk seperti huruf C (saat mati). Jika ragu-ragu larva harus dilihat pada perbesaran yang lebih tinggi dan jaringan harus diperiksa lebih lanjut (OIE 2012). Pada penelitian ini karena pada pengujian digesty masih belum dapat dipastikan bahwa larva yang ditemukan adalan Trichinella spp. maka dilakukan pemeriksaan lebih lanjut yaitu dengan pengujian individual sampel otot dengan metode kompresi dan pewarnaan HE.

Penggunaan utama dari metode kompresi adalah untuk deteksi post mortem. Karena metode ini merupakan metode yang sederhana dan ekonomis dalam pengerjaannya, hal ini secara rutin digunakan 
untuk menyelidiki keberadaan larva Trichinella spp. pada otot, meskipun nilai sensitivitas diagnostik yang tergantung pada pengalaman operator dalam pemeriksaan sampel (Melgar et al., 2007). Dengan kompresi, potongan kecil jaringan otot diafragma babi ditekan diantara dua pelat kaca dan diperiksa dengan seksama menggunakan mikroskop untuk mendeteksi larva Trichinella spp. Hal ini diasumsikan bahwa jaringan yang diperiksa harus mengandung minimal 3 lpg untuk memperoleh hasil deteksi secara handal. Namun, non-encapsulated spesies Trichinella seperti Trichinella pseudospiralis sangat sulit untuk dideteksi dengan metode ini. Oleh karena itu, metode ini tidak direkomendasikan untuk pemeriksaan rutin (Schupper, 2010).

Pemeriksaan dengan metode pengecatan $\mathrm{HE}$ pada sampel tidak ditemukannya bentukan cysta atau nurse cell serta tidak adanya perubahan morfologi sel otot. Menurut Wu et al. (2001), perubahan sel otot pada babi yang terinfeksi Trichinella spp. yang tampak pada pemeriksaan HE yaitu adanya perubahan morfologi segera setelah infeksi oleh larva yang baru lahir dari Trichinella spiralis, sel otot akan kehilangan karakteristik myofibril dan akan bertransformasi ke sel perawat (nurse cell), infeksi Trichinella pseudospiralis juga akan menyebabkan disintegrasi miofibril, meskipun lebih lambat. Secara umum, sarcoplasma akan rusak kemudian serabut otot cepat tertutup untuk meminimalkan nekrosis. Menurut Naibaho et al. (2001), hasil negatif dalam pemeriksaan secara langsung terhadap larva cacing Trichinella spp. dapat dipengaruhi oleh intensitas infeksi yang sangat rendah, sehingga pada pemeriksaan diafragma hasilnya negatif, tetapi kemungkinan larva cacing Trichinella spp. ada di tempat lain. Kemungkinan yang lain adalah karena sistem peternakan yang sudah baik.

Pengujian secara langsung memiliki keterbatasan dalam hal sensitivitas diagnostik dan analitis. Karena alasan ini daging babi dengan pengujian negatif mungkin terinfeksi oleh larva dengan jumlah yang melebihi jumlah yang dianggap aman untuk dikonsumsi manusia. Model respon dosis menunjukkan bahwa konsumsi $100 \mathrm{~g}$ daging babi yang terinfeksi dengan 200 larva mungkin akan teruji negatif dengan metode digesti maupun kompresi tetapi tidak aman untuk konsumsi manusia karena kemungkinan tertular penyakit ini setelah mengosumsi 200 larva cukup besar (Teunisi, 2012).

Larva nematoda yang bermigrasi kadang-kadang dapat ditemukan pada jaringan otot, dan untuk membedakan Trichinella sp. dengan nematoda lainnya diperlukan perbesaran yang kuat sehingga dapat dilakukan identifikasi. Secara teoritis dife- rensial diagnosa umum untuk larva yang dapat ditemukan dalam pengujian digesti terhadap Trichinella spp. diantaranya termasuk Ascaris suum dan Metastrongylus apri. Pengujian infeksi dengan Toxocara canis telah menunjukkan bahwa larva dapat ditemukan pada saat pengujian digesti dikarenakan adanya larva migrans ke tempat predileksinya pada tahap awal infeksi (Davidson et al., 2012).

Temuan negatif pada metode pemeriksaan di atas, tidak menjamin wilayah Manado bebas dari infeksi Trichinella spp., karena pengetahuan yang lengkap tentang situasi epidemiologi parasit pada babi domestik dan satwa liar di Propinsi Sulawesi Utara tidak diketahui. Hasil pengujian daging babi secara rutin dengan metode digesty tidak mampu menunjukkan kebebasan dari infeksi Trichinella spp. pada babi domestik (Gottstein et al., 2009).

Dari hasil pengujian 278 sampel otot babi dengan uji digesti yang dilanjutkan dengan metode kompresi dan pengecatan $\mathrm{HE}$, tidak ditemukan sampel yang terdeteksi Trichinella spp. tetapi program yang menjamin pengujian Trichinella spp. di rumah potong hewan babi maupun di tempat pemotongan hewan babi pada daging babi untuk konsumsi manusia tetap diperlukan agar dapat mendeteksi secara cepat keberadaan Trichinella spp. Promosi pendidikan kepada masyarakat mengenai cara memasak daging untuk menjamin keamanan pangan terutama yang berasal dari daging babi juga diperlukan untuk mencegah penyebaran trichinellosis ke manusia.

\section{UCAPAN TERIMA KASIH}

Terimakasih disampaikan kepada Badan Karantina Pertanian atas dukungannya selama penelitian serta berbagai pihak yang telah membantu terlaksananya penelitian ini.

"Penulis menyatakan tidak ada konflik kepentingan dengan pihak-pihak yang terkait dalam penelitian ini".

\section{DAFTAR PUSTAKA}

Angi AH, Satrija F, Lukman DW, Sudarwanto $M$, Sudarnika E. 2014. Prevalence of Trichinellosis in Pork Meat at Slaughterhouse in Kupang City, East Nusa Tenggara Province. Global Veterinaria. 13: 601-605.

[BPS MANADO] Badan Pusat Statistik Kota Manado. 2014. Statistik Kota Manado 2014. 
http://www.manadoKota.bps.go.id/index. php?hal=publikasi_detail\&id=05. Download: October 20, 2014.

Davidson RK, Mermer A, Oines O. 2012. Toxocara cati larva migrans in domestic pigs- detected at slaughterhouse control in Norway. Acta Veterinaria Scandinavica. 54: 66

[Ditjenakeswan] Direktorat Jenderal Peternakan dan Kesehatan Hewan. 2013. Statistik Peternakan dan Kesehatan Hewan 2013. http://www. mediafire.com/view/5003604mlxjx1wy/Statistik_PKH_Tahun_2013. Pdf. Download: April 1, 2014.

Gottstein B, Pozio E, Nockler K. 2009. Epidemiology, diagnosis, treatment, and control of trichinellosis. Clinical Microbiology Reviews. 22: 12745

Kandou GD. 2009. Kebiasaan makan makanan etnik Minahasa di Provinsi Sulawesi Utara. Jurnal Kesehatan Masyarakat. 3: 53-57.

Kant I, Pandelaki AJ, Lampus BS. 2013. Gambaran Kebiasaan Makan Masyarakat di Perumahan Allandrew Permai Kelurahan Malalayang I Lingkungan XI Kota Manado. Jurnal Kedokteran Komunitas dan Tropik. 1: 88-95.

Karn SK, Horchner F, Srikitjakarn L, Baumann M, Nockler K. 2008. Cross Sectional Study of Trichinella spp. in Pigs in CDR, Nepal Using Pepsin Digestion and ELISA Serology. Southeast Asian Journal of Tropical Medicine and Public Health. 39: 795-799.

[OIE] Office International des Epizooties. 2007. Guidelines for the surveillance, management, prevention and control of trichinellosis. Paris: OIE.

[OIE] Office International des Epizooties. Terrestrial Manual 2012. Chapter 2.1.16. Trichinellosis. Rome (IT): OIE.
Melgar CR, Gomes PA, De-la-Rosa JL. 2007. Application of Giemsa stain for easy detection of Trichinella spiralis muscle larvae. Korean Journal of Parasitology. 45: 65-68.

Naibaho A, Oka IBM, Swacita IBN. 2013. Kualitas Daging Babi Ditinjau Dari Uji Obyektif Dan Pemeriksaan Larva Cacing Trichinella spp. Indonesia Medicus Veterinus. 2: 12-21.

Pozio E. 2005. The broad spectrum of Trichinella spp. hosts: From cold- to warm-blooded animals. Veterinary Parasitology. 132: 3-11.

Pozio E 2007. World distribution of Trichinella spp. infections in animals and humans. Veterinary $\mathrm{Pa}$ rasitology. 149: 3-21.

Samuelson DA. 2007. Textbook of Veterinary Histology. Missouri: Saunders.

Schuppers ME, Frey CF, Gottstein B, Stark KD, Kihh $\mathrm{MU}$, Regula G. 2010. Comparing the demonstration of freedom from Trichinella infection of domestic pigs by traditional and risk-based surveillance. Epidemiology and Infection. 138: 12421251.

Schuppers ME. 2010. Development of a risk-based surveillance program for Trichinella spp. in domestic swine and wildlife in Switzerland. [Dissertation] Wageningen: Wagenigen Univ. p19-34.

Teunisi, P,F,M.., Koningstein, M. Takumi, K. Van Der Giessen J,W,B. 2011. Human beings are highly susceptible to low doses of Trichinella spp. Epidemiology and Infection. 140: 210-218.

Wu Z, Matsuo A, Nakada T, Nagano I, Takahashi Y. 2001. Different response of satellite cells in the kinetics of myogenic regulatory factors and ultrastructural pathology after Trichinella spiralis and T. pseudospiralis infection. Parasitology 123: 85-94 